\title{
Purification and Characterization of Rice Peroxidases ${ }^{\dagger}$
}

\author{
Hiroyuki Ito, Nobutsugu Hrraoka, Akira Ohbayashi* \\ and Yuko OHASHI** \\ Bioproducts Development Center and *Central Research Laboratories, \\ Takara Shuzo Co., Ltd., Seta 3-4-1, Otsu, Shiga 520-21, Japan \\ **Department of Molecular Biology, National Institute of Agrobiological Resources, \\ Tsukuba Science City, Ibaraki 305, Japan
}

Received December 19, 1990

\begin{abstract}
Four peroxidase components, named RP-2, 4, 6, and 7, were isolated from rice (Oryza sativa L.) green leaves. Isoelectric focusing indicated that each preparation was homogeneous. The molecular weights of RP-2, 4, 6, and 7 estimated by SDS-PAGE were 48,000, 48,000, 40,000, and 39,500, and their isoelectric points were $5.4,8.1,9.3$, and 9.2 , respectively. The activity of every preparation was maximum around $\mathrm{pH}$ 5.0. Antisera against these purified enzymes were raised in rabbits. Ouchterlony double diffusion tests with these antisera suggested that RP-6 and 7 were immunochemically identical and RP-2 and 4 were identical in parts and that RP-6 and 7 were quite different from RP-2 and 4. Analysis of the N-terminal amino acid sequences also showed that these peroxidase components were classified into two groups. The polymerase chain reaction showed that RP-2 and/or RP-4 contained an active central region, which is homologous to other plant peroxidases.
\end{abstract}

Peroxidase [EC 1.11.1.7] is an oxidoreductase that catalyzes the oxidation of various proton donors with $\mathrm{H}_{2} \mathrm{O}_{2}$ and carries a $b$-type heme as the prosthetic group. ${ }^{1)}$ Most higher plants have some peroxidase isozymes. ${ }^{1)}$ Many functions of peroxidase isozymes have been postulated, including secondary cell wall biosynthesis, ${ }^{2-4)}$ wound healing, ${ }^{5,6)}$ cell differentiation, ${ }^{7)}$ and resistance against infection by pathogens. ${ }^{8,9)}$ However, the roles of each isozyme are not fully understood. To understand the physiological roles of peroxidase isozymes in plants and to clarify the functions of each isozyme, characterization of the purified peroxidases and identification of their cellular location are necessary. Isolation and characterization of peroxidase isozymes have been reported with dicotyledons, such as tobacco, ${ }^{10}$ ) horseradish, ${ }^{11-13)}$ potato, ${ }^{14)}$ tomato ${ }^{15)}$ and turnip, ${ }^{16)}$ but there are limited reports on monocotyledon peroxidases. ${ }^{17-19)}$ In rice, 17 peroxidase components were electrophoretically detected in the embryo and a cationic peroxidase was found to be a major component. ${ }^{19)}$

In this paper, we report the isolation of four peroxidase components from the green leaves of rice. These components were characterized using biochemical and immunological methods, which included a comparison of the Nterminal sequences. We also report the isolation of a fragment of 90 base pairs encoding RP-2 and/or RP-4.

\section{Materials and Methods}

Rice leaves. Rice (Oryza sativa L. cv. Nipponbare) seedlings were grown for 25 days after sowing at $25^{\circ} \mathrm{C}$ in a temperature-controlled greenhouse. Harvested green leaves were stored at $-80^{\circ} \mathrm{C}$ until use.

Peroxidase activity. The standard reaction mixture, containing I $\mathrm{ml}$ of McIlvaine's buffer ( $\mathrm{pH} 5.0$ ), $0.05 \mathrm{ml}$ of $0.3 \% \quad \mathrm{H}_{2} \mathrm{O}_{2}, 0.05 \mathrm{ml}$ of $1 \%$ o-phenylenediamine, and $0.01 \mathrm{ml}$ of enzyme solution, was incubated at $30^{\circ} \mathrm{C}$. The reaction was stopped with $0.1 \mathrm{ml}$ of $40 \%(\mathrm{w} / \mathrm{v})$ sodium bisulfite and $\mathrm{OD}_{450}$ of oxidized $o$-phenylenediamine was mea-

† This work was supported by the Agrobiological Gene Analysis Research Association (AGARA), Japan. 
sured. One unit of the enzyme activity was defined as the amount of enzyme that increased the $\Delta \mathrm{OD}_{450}$ by $1.0 \mathrm{per}$ minute under the above assay conditions. ${ }^{201}$

Protein measurement. Protein was measured with Micro BCA Protein Assay Reagent (Pierce, U.S.A), using bovine serum albumin as a standard. ${ }^{21}$

Electrophoresis. Sodium dodecyl sulfate (SDS) polyacrylamide gel electrophoresis (PAGE) was done with a ready-made Polyacrylamide Gradient Gel (Daiichi Pure Chemicals Co., Ltd., Japan) by the methods of Laemmii. ${ }^{22)}$ Lysozyme $\left(M_{r}=14,400\right)$, soybean trypsin inhibitor $(21,500)$, carbonic anhydrase $(31,000)$, ovalbumin $(45,000)$, bovine serum albumin $(66,200)$, and phosphorylase B $(92,500)$ were used as molecular weight markers. Isoelectric focusing was done with an IsoGel plate ( $\mathrm{pH}$ range $3-10$, FMC Corp., U.S.A.) at $500 \mathrm{~V}$ for $90 \mathrm{~min}$. Two set of $\mathrm{p} I$ markers were used. One was from Pharmacia Fine Chemicals, Sweden, and consisted of amyloglucosidase ( $\mathrm{p} I=3.5)$, soybean trypsin inhibitor (4.6), $\beta$-lactoglobulin A (5.2), carbonic anhydrase (6.6), myoglobin (7.4), and trypsinogen (9.3). The other was from FMC Corp. and consisted of amyloglucosidase $(\mathrm{p} I=3.6)$, ovalbumin (4.8), $\beta$-lactoglobulin (5.5), carbonic anhydrase (6.1), myoglobin (minor band, 7.7), myoglobin (major band, 8.2), and cytochrome $c$ (10.2). Peroxidase was stained for its activity in McIlvaine's buffer ( $\mathrm{pH} 5.0$ ) containing $0.03 \% \mathrm{H}_{2} \mathrm{O}_{2}$ and $0.1 \%$ 4-chloro-l-naphthol. Preparative PAGE for RP-4 purification was done by the methods of Reisfeld et $a l^{23}$ on a slab gel.

Buffers. Buffer $\mathrm{A}, 0.01 \mathrm{~m}$ sodium acetate buffer $(\mathrm{pH}$ 4.3); Buffer B, $0.01 \mathrm{M}$ sodium acetate buffer ( $\mathrm{pH} 6.5$ ); Buffer C, $0.02 \mathrm{M}$ sodium phosphate buffer ( $\mathrm{pH} 6.8$ ); Buffer $\mathrm{D}$, Buffer $\mathrm{C}$ containing $50 \%(\mathrm{w} / \mathrm{v})$ ammonium sulfate; Buffer $\mathrm{E}$, half the concentration of Buffer D.

Procedure for purification. Rice leaves $(2.6 \mathrm{~kg})$ were frozen in liquid nitrogen and powdered with a homogenizer. Powdered leaves were homogenized in about 4 volumes of McIlvaine's buffer ( $\mathrm{pH} 2.8$ ) containing $0.5 \%$ 2-mercaptoethanol, $10 \mathrm{~mm} \mathrm{Na-ascorbate,} \mathrm{and} 1 \mu \mathrm{M} p$ APMSF (aminophenylmethylsulfonyl fluoride) at $4^{\circ} \mathrm{C}$. The homogenate was filtered through a nylon filter (300$\mu \mathrm{m}$ pores) and the filtrate was centrifuged at $13,500 \times g$ for $10 \mathrm{~min}$. This supernatant (crude extract) was brought to $80 \%$ saturation with solid ammonium sulfate and left at $4^{\circ} \mathrm{C}$ overnight.

The precipitate collected was dissolved in Buffer $\mathrm{A}$ and fractionated with a Sephadex G-25 column $(4 \times 60 \mathrm{~cm})$. The active fractions were dialyzed against Buffer $B$ and put on a CM-Sepharose CL-6B column (1st, $3 \times 20 \mathrm{~cm}$ ) previously equilibrated with the same buffer. After collection of the unabsorbed components (Fraction I, $500 \mathrm{ml}$ ), elution was done with $0.5 \mathrm{M} \mathrm{NaCl}$ in the same buffer (Fraction II, $100 \mathrm{ml}$ ). Fraction I was dialyzed against Buffer $A$ and put on a CM-Sepharose CL-6B column ( $2 \mathrm{nd}, 3 \times 34 \mathrm{~cm}$ ). The active fractions, which were obtained by elution with a linear gradient of $\mathrm{NaCl}$, were separated into three components, $\mathrm{S}-1,2$, and 3 .

The same volume of Buffer D was added to the $S-2$ fraction and put on a phenyl-Sepharose CL-4B column $(1.5 \times 28 \mathrm{~cm})$ equilibrated with Buffer $E$. The non-absorbed fraction was concentrated to $0.5 \mathrm{ml}$ with a Centricon 30 (Amicon Corp., U.S.A.) and placed on a Bio-gel P-60 column $(1.5 \times 28 \mathrm{~cm})$ equilibrated with Buffer $\mathrm{C}$. The active fractions eluted with the same buffer were used as the purified rice peroxidase 2 (RP-2).

Fraction II was brought to $70 \%$ saturation with solid ammonium sulfate. The precipitate obtained was dissolved in $3 \mathrm{ml}$ of Buffer $\mathrm{C}$ and fractionated with a Sephadex G-75 column $(3 \times 55 \mathrm{~cm})$. Two active fractions, named S-4 and 5 , were obtained.

Although the $S-4$ fraction was added to the same volume of Buffer $D$ and the mixture was put on a phenyl-Sepharose column $(1.5 \times 28 \mathrm{~cm})$, peroxidase activity was detected in the non-absorbed fraction. Therefore, the active fraction was concentrated to $3 \mathrm{ml}$ and put on a Sephadex G-100 column $(1.5 \times 80 \mathrm{~cm})$ to remove ammonium sulfate. Glycerol was added to the fraction to a final concentration of $20 \%$, and the mixture was used for preparative PAGE (pH 4.3) with a $7.5 \%$ slab gel. Peroxidase protein in the gel was observed as an orange-colored band. This band was also positive for active staining for peroxidase. Peroxidase was extracted by Buffer $\mathrm{C}$ from the band. The extract was concentrated to $0.5 \mathrm{ml}$ and fractionated with a Sephadex G-75 column $(1.5 \times 28 \mathrm{~cm})$ to remove compounds with low molecular weights, including salts. The active fractions eluted with the same buffer were recovered as the purified rice peroxidase 4 (RP-4).

The S- 5 fraction was put on a phenyl-Sepharose CL-4B column $(2 \times 30 \mathrm{~cm})$ and the enzymes were eluted with a reverse linear gradient of ammonium sulfate (25 to $0 \%$ ) and a linear gradient of ethylene glycol ( 0 to $50 \%)$ at the same time. The active fractions were separated into four components, S-6, 7, 8, and 9. S-6 (Frs. 18-26) and S-7 (Frs. 28-36) were concentrated to $0.5 \mathrm{ml}$ and placed on a Bio-gel P-60 column $(2 \times 47 \mathrm{~cm})$ pre-equilibrated with Buffer $\mathrm{C}$ to get rice peroxidase 6 (RP-6) and 7 (RP-7), respectively.

Analysis of peroxidase components. Isoelectric focusing of crude extract $(20 \mu \mathrm{l})$ was done using the method described under Electrophoresis. After gel electrophoresis, crude proteins were transferred to a nitrocellulose membrane (Nitroplus 2000, MSI Corp, U.S.A.). Staining of peroxidase activity (zymogram) was done in McIlvaine's buffer ( $\mathrm{pH} 5.0$ ) containing $0.03 \% \mathrm{H}_{2} \mathrm{O}_{2}$ and $0.01 \%$ 4chloro-1-naphthol.

Optimum $p H$. The dependency of the activity on $\mathrm{pH}$ was measured in a reaction mixture containing $1 \mathrm{ml}$ of Britton-Robinson's buffer, $0.05 \mathrm{ml}$ of $0.3 \% \mathrm{H}_{2} \mathrm{O}_{2}, 0.05 \mathrm{ml}$ 
of $1 \%$ o-phenylenediamine, and $0.01 \mathrm{ml}$ of enzyme solution. The reaction was done at $30^{\circ} \mathrm{C}$ for $5 \mathrm{~min}$.

pH-stability. The enzyme preparation was kept in a mixture containing $0.01 \mathrm{ml}$ of enzyme solution and $0.09 \mathrm{ml}$ of Britton-Robinson's buffer at $20^{\circ} \mathrm{C}$ for $20 \mathrm{hr}$. Then the peroxidase activity was measured after addition of $1 \mathrm{ml}$ of McIlvaine's buffer ( $\mathrm{pH} 5.0$ ), $0.05 \mathrm{ml}$ of $\mathrm{H}_{2} \mathrm{O}_{2}$, and $0.05 \mathrm{ml}$ of $1 \% o$-phenylenediamine.

Temperature-stability. The enzyme preparation was kept in a mixture containing $0.01 \mathrm{ml}$ of enzyme solution and $1 \mathrm{ml}$ of Mcllvaine's buffer ( $\mathrm{pH} 5.0$ ) at various temperatures for $20 \mathrm{~min}$, and then $0.05 \mathrm{ml}$ of $0.3 \% \mathrm{H}_{2} \mathrm{O}_{2}$ and $0.05 \mathrm{ml}$ of $1 \%$ o-phenylenediamine were added before assaying the enzyme activity at $30^{\circ} \mathrm{C}$.

Preparation of antisera and immunodiffusion. Specific antisera against purified peroxidase components were prepared. ${ }^{24.25)}$ One milliliter of $0.9 \% \mathrm{NaCl}$ solution containing rice peroxidase (about $0.33 \mathrm{mg}$ ) was mixed with the same volume of Freund's complete adjuvant and injected subcutaneously into a rabbit. On day 10 and day 20 after the first injection, $2 \mathrm{ml}$ of the emulsified mixture was injected into the same rabbit as the second and third immunization. Eight days after the third injection, the antiserum was obtained from the carotid artery and was stored at $-80^{\circ} \mathrm{C}$ until use. Immunodiffusion on a $1 \%$ agarose was done at $37^{\circ} \mathrm{C}$ for $24 \mathrm{hr}$ in a moisture chamber. ${ }^{263}$

Analysis of the $N$-terminal amino acid sequence. The $\mathrm{N}$-terminal amino acids of rice peroxidase components were sequenced with an Applied Biosystems 477A gasphase protein sequencer (ABI Corp., U.S.A.). The phenylthiohydantoin (PTH) derivatives of amino acids were identified using the Applied Biosystems $120 \mathrm{~A}$ analyzer connected directly to the sequencer.

DNA isolation. The preparation of rice DNA from 25-day-old leaves was done by the method of Murray and Thompson. ${ }^{27)}$

Polymerase chain reaction $(P C R)$ and nucleotide sequencing. The PCR amplification was done in a DNA Thermal Cycler (Perkin Elmer Cetus, U.S.A.) using two primers (named NT and AS primer, Fig. 7A), specific for an N-terminal region of RP-2 or 4 and the active central region of plant peroxidases. ${ }^{10,28)}$ The amplification reaction mixture of $100 \mu \mathrm{l}$ consisted of $1.0 \mu \mathrm{g}$ rice DNA, $20 \mathrm{pmol}$ NT primer, 20 pmol AS primer, $0.02 \%$ gelatin, $1 \mathrm{mM}$ each dNTP, and 2.5 U AmpliTaq ploymerase in Taq buffer [ $10 \mathrm{~mm}$ Tris- $\mathrm{HCl}(\mathrm{pH} 8.3), 50 \mathrm{mM} \mathrm{KCl}$, and $1.5 \mathrm{~mm}$ $\left.\mathrm{MgCl}_{2}\right]$. The DNA denaturation was set at $94^{\circ} \mathrm{C}$ for $1 \mathrm{~min}$, the primer annealing at $42^{\circ} \mathrm{C}$ for $2 \mathrm{~min}$, and the primer extension at $72^{\circ} \mathrm{C}$ for $2 \mathrm{~min}$. The reaction was run for 30 cycles. The PCR products were analyzed with $4 \%$ NuSieve
3: 1 Agarose (FMC Corp.) and were further purified from the gel. The purified products were subcloned into the HincII site of M13mpl8 vector ${ }^{29)}$ (Takara Shuzo, Japan). Nucleotides were sequenced by the dideoxy chain termination method, ${ }^{30}$ except that 7-deaza-dGTP was used instead of dGTP. The sequences were deduced for both strands.

\section{Results}

\section{Peroxidase components in rice green leaves}

When the crude extract ( $c f$. Fig. 2 and Table I) was tested by isoelectric focusing and the gel was stained for peroxidase activity, at least twenty-five active bands were detected (Fig. 1). Seven of the peroxidase components (Nos. 5, 6, $13,21,22,23$, and 25 ) were major components.

(A)

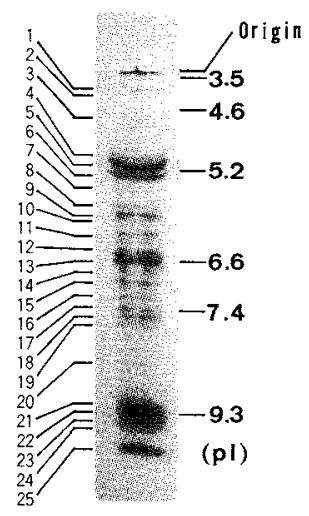

(B)

\begin{tabular}{rrrrrrrr}
\hline No. & pl & No. & pl & No. & pl & No. & pl \\
\hline 1 & 4.0 & 8 & 5.9 & 15 & 6.9 & 22 & 9.3 \\
2 & 4.2 & 9 & 6.0 & 16 & 7.2 & 23 & 9.5 \\
3 & 4.8 & 10 & 6.1 & 17 & 7.4 & 24 & 9.6 \\
4 & 5.1 & 11 & 6.3 & 18 & 7.9 & 25 & 9.9 \\
5 & 5.4 & 12 & 6.4 & 19 & 8.1 & & \\
6 & 5.5 & 13 & 6.6 & 20 & 8.7 & & \\
7 & 5.7 & 14 & 6.7 & 21 & 9.2 & & \\
\hline
\end{tabular}

Fig. 1. Isoelectric Focusing of Peroxidase Components of Crude Extract.

(A): Zymogram pattern of crude extract $(20 \mu \mathrm{l})$. (B): Isoelectric points of each components. The experimental details are given in Materials and Methods. 


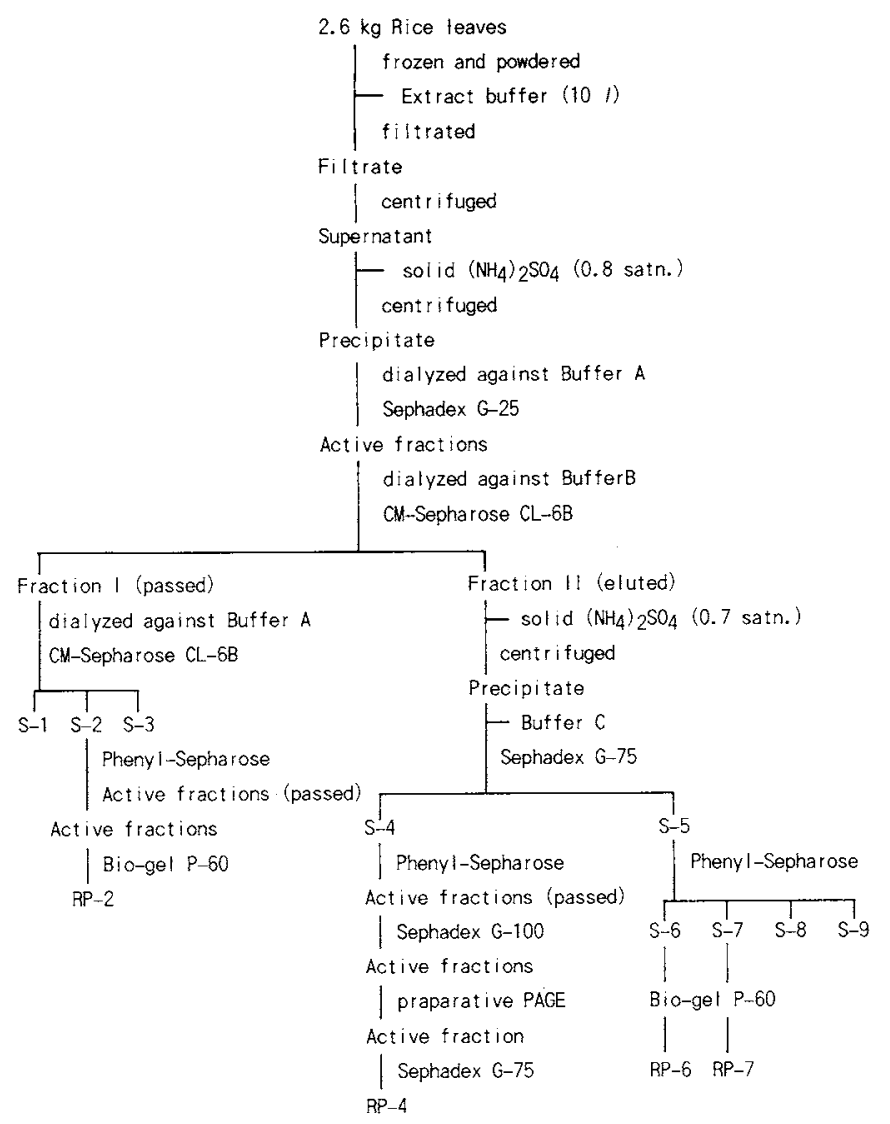

Fig. 2. Purification Steps of Rice Peroxidase Components.

Details are described in Materials and Methods.

\section{Purification of peroxidase components}

According to the scheme shown in Fig. 2, RP-2, 4, 6, and 7 were purified from the S-2, S-4, S-6, and S-7 fractions, respectively. The purification of four peroxidase components is summarized in Table I. The specific activities (U/mg protein) were $72,000,122,000,113,000$, and 104,000 for RP-2, 4, 6, and 7, respectively. The RZ (Reinheitszahl) value ${ }^{1)}\left(A_{408} / A_{280}\right)$ almost reflects the extent of purity of hemoproteins. The RZ values for four components were 2.2 to 2.6 and were close to the values for the other purified peroxidases. ${ }^{1,17)}$

\section{Isoelectric points and molecular weights}

Every purified rice peroxidase component migrated as a clear single protein band when run on an analytical electric focusing gel (Fig. 3). The isoelectric points of RP-2, 4, 6, and 7 were estimated to be $5.4,8.1,9.3$, and 9.2, respectively. The molecular weights of RP-2, 4,6 , and 7 were estimated using SDS-PAGE to be $48,000,48,000,40,000$, and 39,500 , respectively (Fig. 4).

\section{Effects of $p H$ and temperature on the stability andlor activity}

As shown in Table II, each enzyme preparaion was most active around $\mathrm{pH} 5.0$ at $30^{\circ} \mathrm{C}$. More than $90 \%$ of the original activity remained after incubation at $20^{\circ} \mathrm{C}$ for $20 \mathrm{hr}$ between $\mathrm{pH}$ 5.0-11.5 for RP-2 and 4, and 6.0-8.0 for RP-6 and 7 (Table II). Almost no inactivation occurred when the enzyme was kept at pH 5.0 for $20 \mathrm{~min}$ for up to $40^{\circ} \mathrm{C}$ for $\mathrm{RP}-2$, up to $45^{\circ} \mathrm{C}$ for RP-4, and up to $55^{\circ} \mathrm{C}$ for RP-6 and 7 (Table II). 
Table I. Purification of Rice Peroxidase Components

\begin{tabular}{lcccccc}
\hline Step & $\begin{array}{c}\text { Total } \\
\text { protein } \\
(\mathrm{mg})\end{array}$ & $\begin{array}{c}\text { Total } \\
\text { activity } \\
\left(\mathrm{U} \times 10^{-5}\right)\end{array}$ & $\begin{array}{c}\text { Total } \\
A_{408}\end{array}$ & $\begin{array}{c}\text { RZ value } \\
\left(A_{408} / A_{280}\right)\end{array}$ & $\begin{array}{c}\text { Specific } \\
\text { activity } \\
(\mathrm{U} / \mathrm{mg})\end{array}$ & $\begin{array}{c}\text { Yield } \\
(\%)\end{array}$ \\
\hline $\begin{array}{l}\text { Crude extract } \\
\text { CM-Sepharose (1st) }\end{array}$ & $614,800^{a}$ & 57 & 8,940 & 0.015 & $--^{b}$ & 100 \\
$\quad$ Fraction I & $2,035^{a}$ & 14 & 225 & 0.11 & 688 & 25 \\
$\quad$ Fraction II & $217^{a}$ & 27 & 101 & 0.47 & 12,400 & 47 \\
CM-Sepharose (2nd) & & & & & & \\
$\quad$ S-2 & 17.4 & 2.4 & 9.1 & 0.85 & 13,800 & 4.2 \\
Bio-gel (RP-2) & 2.5 & 1.8 & 3.3 & 2.2 & 72,000 & 3.2 \\
Sephadex G-75 & & & & & & \\
S-4 & 84.9 & 12 & 16.8 & 0.35 & 14,100 & 21 \\
$\quad$ S-5 & 61.8 & 22 & 35.5 & 0.84 & 35,600 & 39 \\
Sephadex (RP-4) & 2.3 & 2.8 & 3.2 & 2.5 & 122,000 & 4.9 \\
Phenyl-Sepharose & & & & & & \\
S-6 & 4.1 & 3.4 & 6.1 & 1.9 & 82,900 & 6.0 \\
$\quad$ S-7 & 9.1 & 6.5 & 12.0 & 2.2 & 71,400 & 11 \\
Bio-gel & 1.5 & 1.7 & 3.1 & 2.6 & 113,000 & 3.0 \\
RP-6 & 2.5 & 2.6 & 3.9 & 2.6 & 104,000 & 4.6 \\
RP-7 & & & & & \\
\hline
\end{tabular}

Rice peroxidases were extracted from $2.6 \mathrm{~kg}$ of green rice leaves and purified by the procedure described in Fig. 2 .

a These values were calculated under the assumption that $E_{1 \mathrm{~cm}}^{1 \%}$ at $280 \mathrm{~nm}$ is 10.0 , provided that for crude extract this value was equivalent to total $A_{280}$ to show the RZ value.

$b$ Total protein of crude extract was not measured with accuracy.

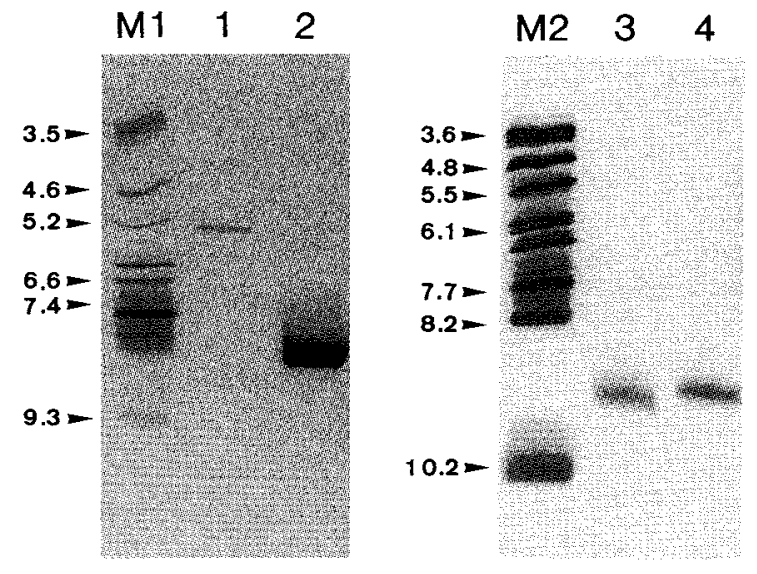

Fig. 3. Isoelectric Focusing of Rice Peroxidases.

Details are described in Materials and Methods. The amount of protein treated by isoelectric focusing were about $1 \mu \mathrm{g}$ for RP-2, $5 \mu \mathrm{g}$ for RP-4, $2.5 \mu \mathrm{g}$ for RP-6, and $2.5 \mu \mathrm{g}$ for RP-7. Lane M1, pI marker (Pharmacia Fine Chemicals); lane M2, pI marker (FMC Corp.); lane 1, RP-2; lane 2, RP-4; lane 3, RP-6; lane 4, RP-7.

\section{Immunodiffusion}

Immunological properties of rice peroxidase components were analyzed by Ouchterlony double diffusion tests (Fig. 5). RP-2 and 4 formed a crossed immunoprecipitin line with a spur (Figs. 5A and B), showing that the en- zymes are immunologically similar and share a common antigen determinant. On the other hand, the immunoprecipitin lines for RP- 6 and 7 were completely fused (Figs. 5C and D), indicating that they were immunologically identical. The antisera against RP-6 and 7 


\section{$M 1 M 2 M 34$}

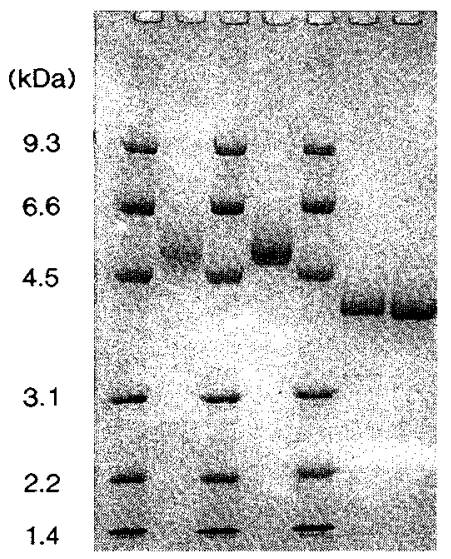

Fig. 4. Estimation of the Molecular Weights of Rice Peroxidases by SDS-PAGE.

Lane $\mathrm{M}$, molecular weight marker (BIO-RAD); lane 1, RP-2 $(3 \mu \mathrm{g})$; lane 2, RP-4 (4 $\mu \mathrm{g})$; lane 3, RP-6 (4 $\mu \mathrm{g})$; lane $4, \operatorname{RP}-7(4 \mu \mathrm{g})$.

Table II. EFFects of pH AND Temperature on STABILITY AND ACTIVITY

\begin{tabular}{lccc}
\hline Components & $\begin{array}{c}\text { Optimum } \\
\mathrm{pH}^{a}\end{array}$ & $\begin{array}{c}\mathrm{pH} \text { stability } \\
\text { range }^{b}\end{array}$ & $\begin{array}{c}\text { Temperature } \\
\text { stability }\left({ }^{\circ} \mathrm{C}\right)^{c}\end{array}$ \\
\hline RP-2 & 5.1 & $5.0-11.5$ & 40 \\
RP-4 & 5.3 & $5.0-11.5$ & 45 \\
RP-6 & 4.7 & $6.0-8.0$ & 55 \\
RP-7 & 4.8 & $6.0-8.0$ & 55 \\
\hline
\end{tabular}

a $\mathrm{pH}$ with maximum activity under the conditions described in Materials and Methods.

${ }^{b} \mathrm{pH}$ range in which more than $90 \%$ of the residual activity remained after being treated as described in Materials and Methods.

c Temperature limit within which more than $90 \%$ of the original activity remained after being treated as described in Materials and Methods and the text.

formed no immunoprecipitin line with RP-2 and 4 . These results indicate that four peroxidase components can be classified into two groups by their immunological properties: one group consisting of RP-2 and 4, and the other consisting of RP-6 and 7.

\section{$N$-Terminal amino acid sequence}

Figure $6 \mathrm{~A}$ shows the $\mathrm{N}$-terminal sequences of peroxidase components isolated in this work. Although the isoelectric point of RP-2 was
A

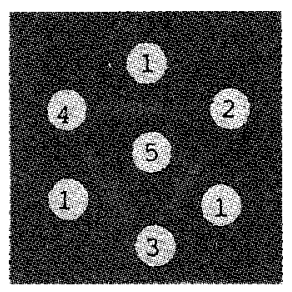

C
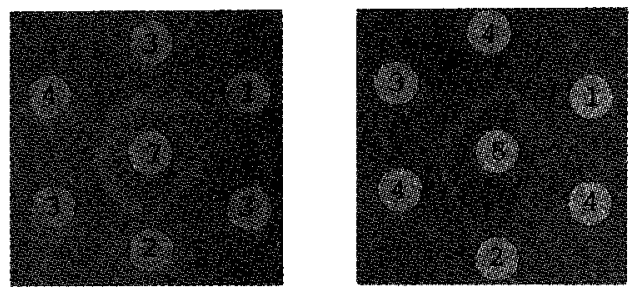

Fig. 5. Ouchterlony Double Diffusion Analysis.

Well 1, RP-2 (2.5 $\mu \mathrm{g})$; well 2, RP-4 (2.0 $\mu \mathrm{g})$; well 3, RP-6 $(1.7 \mu \mathrm{g})$; well 4 , RP-7 $(2.0 \mu \mathrm{g})$; well 5 , antiserum against RP-2 $(5 \mu 1)$; well 6 , antiserum against RP-4 $(5 \mu 1)$; well 7 , antiserum against RP-6 $(5 \mu 1)$; well 8 , antiserum against RP-7 $(5 \mu \mathrm{l})$. Details are described under Materials and Methods.

different from that of RP-4, their amino acid sequences were almost the same. This suggests that there are differences in the amino acid sequence in a region other that the N-terminal region between them. The sequences of RP-6 and 7 with similar isoelectric points were very similar to each other. These data support the proposition that the peroxidase components can be classified into two groups.

The amino acid sequences were also compared to the sequences of peroxidases from dicots like tobacco, horseradish, and turnip (Fig. 6B). The best alignment of these peroxidases is shown. The N-terminal is blocked in a form of pyrrolidonecarboxyl residue for tobacco, ${ }^{10)}$ horseradish, ${ }^{11)}$ and turnip peroxidases. ${ }^{16)}$ In purified rice peroxidase components, however, their $\mathrm{N}$-terminals were not blocked.

\section{The existence of the gene coding for RP-2 or 4}

Previous papers ${ }^{10,28)}$ on the amino acid sequences of plant peroxidases have suggested 

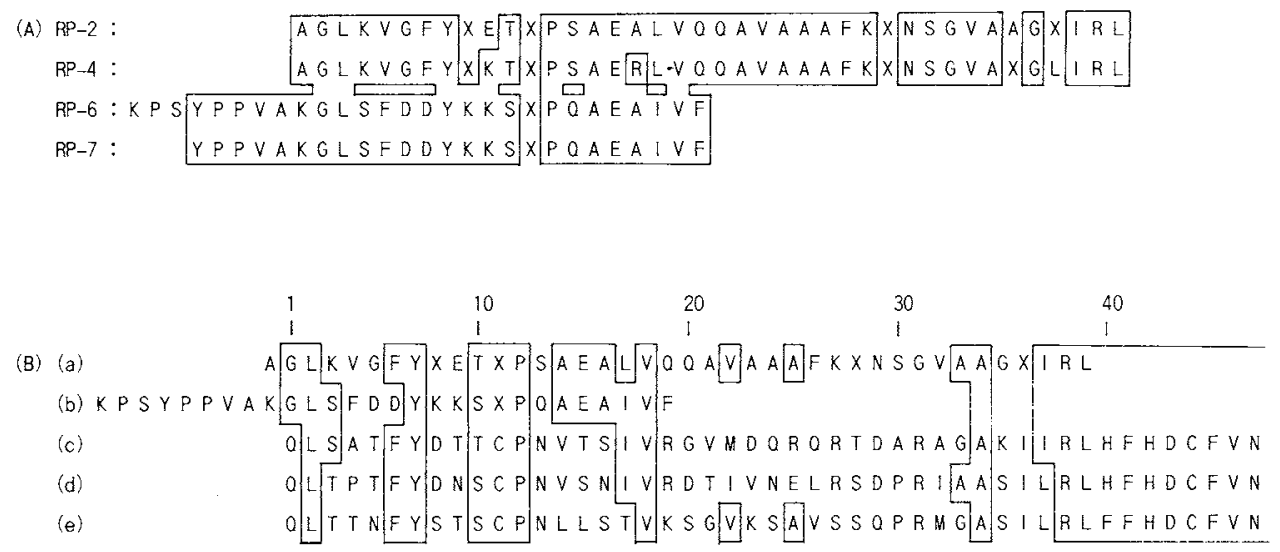

Fig. 6. Analysis of N-Terminal Amino Acid Sequences.

Analysis was done by automated Edman degradation as described in Materials and Methods. The one-letter amino acid notation is used. A, The best alignment of RP-2, 4, 6, and 7 is shown. Common regions in the sequences are boxed. B, The best alignment of RP-2 (a), RP-6 (b), tobacco peroxidase (c), horseradish peroxidase $\mathrm{Cla}$ (d), and turnip peroxidase (e) is shown. Residues common to RP-2 or RP-6 shown here are boxed.

that a mature peroxidase consisted of about 300 amino acid residues and had three highly-conserved regions. To get information on the genes coding for RP-2 and RP-4, PCR of rice genomic DNA was conducted. Two primers (Fig. 7A) were synthesized; one (NT primer) was specific for the $\mathrm{N}$-terminal region of RP-2 or 4, and the other (AS primer) corresponded to the active site of plant peroxidases. A fragment of 90 base pairs was amplified by the PCR of rice genomic DNA using these primers (Fig. 7B). The fragment was then subcloned into $\mathrm{M} 13 \mathrm{mp} 18$ vector and the nucleotides were sequenced (Fig. 7C). The amino acid sequence deduced from the nucleotide sequence agreed completely with the $\mathrm{N}$-terminal sequence of RP-2 or 4 (Figs. 6A and $7 \mathrm{C}$ ).

\section{Discussion}

We separated peroxidase isozymes (isoforms) from green leaves of rice seedlings and prepared eight isozyme fractions (S-1, 2, 3, 4, $6,7,8$, and 9); four of them (RP-2, 4, 6, and 7) were in highly purified states. We also partially purified another peroxidase isozyme (termed RP-I) from 110-day old rice green leaves; this isozyme was the major form in the mature leaves (data not shown). Judging from isoelectric point $(\mathrm{p} I=6.0)$ and immunochemical nature, the isozyme in S-3 fraction was similar to RP-I. In young green leaves, RP-I was a minor activity, suggesting that the relative amount of each peroxidase isozyme may have been changed by the physiological state.

In rice leaves, we detected at least twenty-five peroxidase components by isoelectric focusing (Fig. 1). Six components with $\mathrm{p} I \mathrm{~s}$ of 5.4, 5.5, $6.6,9.2,9.3$, and 9.9 were major components; four of them (Fig. 1; No. 1 to 4) were more anionic than RP-2 and three (Fig. 1; No. 23 to 25) were more cationic than RP-6.

Immunological analysis showed that the four purified peroxidase components can be divided into two groups. Antisera raised against these purified rice peroxidase components did not react with purified tobacco anionic peroxidase or horseradish peroxidases (data not shown). Further, antisera raised against RP-6 and 7 did not form any immunoprecipitin line with RP-2 and 4 (Figs. 5C and D). Generally, peroxidases have sugar moieties, and the polyclonal antibody raised against the enzyme may contain the antibodies corresponding to the glycosid- 
$\begin{array}{lrrrrrrrrrr}\text { a) a. } & V & Q & Q & A & V & A & A & A & F & K \\ \text { mRNA } & \text { GUN } & \text { CAA } & \text { CAA } & \text { GCN } & \text { GUN } & \text { GCN } & \text { GCN } & \text { GCN } & \text { UUU } & \text { AAA } \\ & & G & G & & & & & & \text { C } & G\end{array}$

primer 5'-GTI CAG CAG GCI GTI GCI GCI GCI TTT AA-3'

(29 mer)

b) a.a.

mRNA

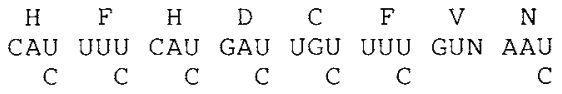

primer $3^{\prime}-$ GTA AAG GTA CTG ACG AAA CAI TT-5'

(23 mer)

(B)

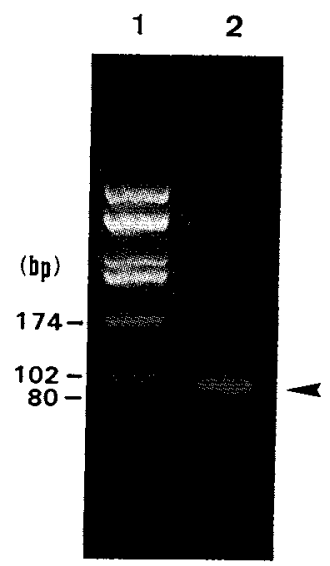

$\begin{array}{llllllllllllllll}\text { (C) } & V & Q & Q & A & V & A & A & A & E & K & N & N & S & G & V\end{array}$ GTG CAG CAG GCG GTG GCG GCG GCG TPT AAG AAC AAC AGC GGC GTC

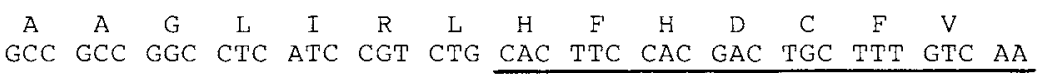

Fig. 7. The Polymerase Chain Reaction and Analysis of the PCR Products.

(A): Protein sequence data and the synthetic oligonucleotide primer used in the PCR: a), a portion of $\mathrm{N}$-terminal amino acid sequence of RP-2 or 4, followed by the deduced mRNA sequence, and the synthetic oligonucleotide sequence as the NT primer; b), a portion of amino acid sequence of the active central region, ${ }^{25}$ followed by the deduced $m$ RNA sequence, and the synthetic oligonucleotide sequence as AS primer. (B): Analysis of the PCR products $(20 \mu \mathrm{l})$. (C): Nucleotide and deduced amino acid sequence of the PCR products. One-letter amino acid notation is used. The underlinings correspond to sequences of the primers.

ic chains. However, the above data suggest that the four antisera have specificity to recognize their own antigens, probably specific amino acid sequences of the antigens.

Following Ouchterlony tests, the agarose plates were activity-stained. All precipitin lines turned purple, which suggests that the pre- cipitated proteins have peroxidase activity. The active sites of these peroxidases may differ from the reactive site of antigen-antibody reaction.

There was no clear homology in the amino acid sequences of the $\mathrm{N}$-terminal regions of various plant peroxidases. However, the ac- 
tive site $^{28)}$ of tobacco, ${ }^{10)}$ horseradish, ${ }^{11)}$ and turnip $^{16)}$ peroxidase, comprise a highly conserved sequence containing about 25 amino acid residues starting from isoleucine or leucine (residue No. 37 in Fig. 6B). A comparison of $\mathrm{N}$-terminal sequences suggests that RP-2 and 4 may be similar to dicotyledon peroxidases (Fig. 6B).

Measurement of $\mathrm{pH}$ and temperatue stability (Table II) indicated that RP-2 and 4 were stable at a wide range of $\mathrm{pH}$ and relatively sensitive to high temperature, while RP-6 and 7 were stable in a narrow $\mathrm{pH}$ range arond neutral and relatively resistant to high temperature. Although the optimum $\mathrm{pH}$ of these four peroxidases were almost the same, the difference in $\mathrm{pH}$ and temperature stability suggests that the two types of peroxidases may have different physiological roles and/or may be localized in different tissues.

Using PCR, it was confirmed that RP-2 and/or 4 have their active central regions which are homologous to other plant peroxidases (Figs. 6B and 7C). DNA sequence data of the multiplied fragment also showed the absence of introns in the region between the $\mathrm{N}$-terminal and the active site of the peroxidase gene.

These biochemical studies, analysis of the $\mathrm{N}$-terminal amino acid sequences, and studies using PCR suggest the presence of two types of rice peroxidase genes. We have already obtained two kinds of putative peroxidase cDNA clones from rice leaves (unpublished data). However, the $\mathrm{N}$-terminal amino acid sequences deduced from the DNA sequences of the two putative cDNA clones were quite different from those of purified peroxidase components. This suggests that the cDNAs may correspond to different peroxidase isozymes in rice leaves and that at least 4 peroxidase genes may exist in the rice genome.

The functions of the two types of rice peroxidases which we have purified are not clear. We have observed that the peroxidase isozyme pattern changes with physiological conditions, especially with developmental stages. Analysis of changes in the content of each peroxidase at various developmental stages or after pathogen infection may be necessary to elucidate their functions. Experiments on cell localization $^{31,32)}$ may also be helpful for understanding the functions of peroxidases. The antisera prepared in this study will be useful to us for studies on the localization of these peroxidases. Such experiments are now being undertaken in our laboratory.

Acknowledgments. We thank Dr. M. Matsuoka of the National Institute of Agrobiological Resources for helpful discussion and Mr. M. Ito of Biotechnology Research Laboratories, Takara Shuzo Co., Ltd., for N-terminal amino acid sequence analysis. We thank Mrs. M. Nakatsuji for her technical assistance.

\section{References}

1) R. B. van Huystee, Annal. Rev. Plant Physiol., 38, 205 (1987).

2) N. G. Lewis, R. A. Razal and E. Yamamoto, Proc. Natl. Acad. Sci. U.S.A., 84, 7925 (1987).

3) K. E. Espelie, V. R. Franceschi and P. E. Kolattukudy, Plant Physiol., 81, 487 (1986).

4) J. Negrel and J. Lherminier, Planta, 172, 494 (1987).

5) K. E. Espelie and P. E. Kolattukudy, Arch. Biochem. Biophys., 240, 539 (1985).

6) L. M. Lagrimini and S. Rothstein, Plant Physiol., 84, 438 (1987).

7) O. P. Srivastave and R. B. van Huystee, Phytochemistry, 16, 1527 (1977).

8) H. Bireka and A. Miller, Plant Physiol., 53, 569 (1974).

9) S. J. Sheen and S. Diachun, Acta Phytopathologica Academiae Scientiarum Hungaricae, 13, 21 (1978).

10) L. M. Lagrimini, W. Burkhart, M. Moyer and S. Rothstein, Proc. Natl. Acad. Sci. U.S.A., 84, 7542 (1987).

11) K. G. Welinder, FEBS Lett., 72, 19 (1976).

12) K. G. Welinder, Eur. J. Biochem., 96, 483 (1979).

13) K. Fujiyama, H. Takamura, S. Shibayama, K. Kobayashi, J-K. Choi, A. Shinmyo, M. Takano and H. Okada, Eur. J. Biochem., 173, 681 (1988).

14) R. Elizabeth, K. Toni and P. E. Kolattududy, Plant Mol. Biol., 11, 15 (1988).

15) R. Elizabeth and P. E. Kolattukudy, Mol. Gen. Genet., 217, 233 (1989).

16) G. Mazza and K. G. Welinder, Eur. J. Biochem., 108, 481 (1980)

17) K. Saeki, O. Ishikawa, T. Fukuoka, H. Nakagawa, Y. Kai, T. Kakuno, J. Yamashita, N. Kasai and T. Horio, J. Biochem., 99, 485 (1986)

18) Y. Morita and S. Ida, Agric. Biol. Chem., 32, 441 
(1968).

19) S. Ida, I. Kitamura, H. Nikaido and Y. Morita, Agric. Biol. Chem., 36, 611 (1972).

20) Y. Kanazawa, H. Shichi and I. Uritani, Agric. Biol. Chem., 29, 840 (1965).

21) P. K. Smith, R. I. Krohn, G. T. Hermanson, A. K. Mallia, F. H. Gartner, M. D. Provenzano, E. K. Fujimoto, N. M. Goeke, B. J. Olson, and D. C. Klenk, Anal. Biochem., 150, 76 (1985).

22) U. K. Laemmli, Nature, 227, 680 (1970).

23) R. A. Reisfeld, V. J. Lewis and D. E. Williams, Nature, 195, 281 (1962).

24) P. H. Mavrer and H. J. Challahan, in "Method in Enzymology," Vol. 70, ed. by H. van Hunakis and J. J. Langone, Academic Press, New York, 1980, p. 49.

25) B. A. L. Hurn and S. M. Chantler, in "Method in
Enzymology," Vol. 70, ed. by H. van Hunakis and J. J. Langone, Academic Press, New York, 1980, p. 104.

26) J. Oudin, in "Method in Enzymology," Vol. 70, ed. by H. van Hunakis and J. J. Langone, Academic Press, New York, 1980, p. 166.

27) M. G. Murray and W. F. Thompson, Nucl. Acids Res., 8, 4321 (1980).

28) A. Shinmyo, Cell Technology, 7, 588 (1988) (in Japanese).

29) C. Yanisch-Perron, J. Vieira and J. Messing, Gene, 33, 103 (1985).

30) F. Sanger, S. Nicklen and A. R. Coulson, Proc. Natl. Acad. Sci. U.S.A., 74, 5463 (1977).

31) P. S. C. Walter and M. Mader, Planta, 170, 255 (1987).

32) R. W. Parish, Planta, 123, 1 (1975). 